\title{
Numerical Taxonomy and DNA Relatedness of Tropical Rhizobia Isolated from Hainan Province, China
}

\author{
J. L. GAO, J. G. SUN, † Y. LI, E. T. WANG, AND W. X. CHEN* \\ Department of Microbiology, College of Biology, Beijing Agricultural University, \\ Beijing 100094, People's Republic of China
}

\begin{abstract}
A total of 63 strains of rhizobia isolated from Hainan Province, a tropical region of the People's Republic of China, and 27 representative strains belonging to the genera Rhizobium, Bradyrhizobium, and Agrobacterium were compared by performing numerical taxonomy, DNA hybridization, and DNA base composition analysis to determine the relationships among these rhizobia. The results indicated that the strains isolated from Hainan Province fell into two distinct phena, the slowly growing rhizobia and the fast-growing rhizobia. The slowly growing rhizobia, which formed three subphena that seemed to be three subspecies, are Bradyrhizobium japonicum strains. The fast-growing strains belong to the genus Rhizobium and might be further divided into three specific groups. Sometimes both slowly growing rhizobia and fast-growing rhizobia were isolated from host plants belonging to the same genus or species or even from the same nodule. There was no correlation between hosts and the distribution of rhizobia in the subphena. Isolates obtained from members of the same host genus or species fell into different groups or subgroups.
\end{abstract}

The root nodule bacteria of tropical leguminous plants have been investigated by workers in many laboratories $(1$, $5-8,10,23,25)$, but taxonomic studies of these bacteria have been sparse and have been limited to a few leguminous symbionts $(16,19,24,27,28)$. Dreyfus and Dommergues (6) classified 13 Acacia species into three groups on the basis of effective nodulation with fast-growing and slowly growing tropical strains of rhizobia. The first group formed nodules effectively with slow growers; the second group formed effective nodules with fast growers; and the third group formed effective nodules with both fast and slow growers. Zhang et al. (27) obtained 12 clusters by using numerical taxonomy to study 97 strains isolated from root nodules of Acacia senagal, Prospopis chilensis, and other legumes. Thus, it is interesting to study the taxonomy of rhizobia isolated from a wide range of tropical legumes.

In this work 63 rhizobial strains were isolated from various legumes, including trees, herbs, and vines, growing in different geographic regions of Hainan Province of the People's Republic of China, a tropical region south of latitude $20^{\circ} \mathrm{N}$. These strains were compared with previously described species of rhizobia by performing numerical taxonomy, DNA composition, and DNA-DNA hybridization analysis.

\section{MATERIALS AND METHODS}

Bacterial strains. A total of 90 strains were used in this study (Table 1); 27 of these strains were type and representative strains of Rhizobium, Bradyrhizobium, and Agrobacterium species, and 63 strains were isolated from root nodules collected in different geographic regions of Hainan Province. The purity of the cultures was assured by using single-colony isolates and checking colony morphology, bacterial morphology, and the Gram stain reaction. The identity of each strain was checked by performing a plant infection test with the original host plant.

\footnotetext{
* Corresponding author. Telex: 222487 BAU CN. Fax: 86-12582332

$\dagger$ Present address: Department of Microbiology, Soils and Fertilizers Research Institute, Chinese Academy of Agricultural Science, Beijing, People's Republic of China.
}

Characteristics analyzed. The following characteristics were analyzed: (i) utilization as sole carbon sources of L-alanine $(0.1 \%)$, ammonium tartrate $(0.1 \%)$, amygdalin $(0.1 \%)$, D-arabinose $(0.1 \%)$, D-arabitol $(0.1 \%)$, D-arginine $(0.1 \%)$, DL-arginine $(0.1 \%)$, DL-asparagine $(0.1 \%)$, DL-aspartic acid $(0.1 \%)$, calcium gluconate $(0.1 \%)$, calcium malonate $(0.1 \%)$, D $-(+)$-cellobiose $(0.1 \%)$, iso-cytosine $(0.1 \%)$, dextrin $(0.1 \%), 2,4$-dimethoxybenzoate $(0.1 \%)$, dulcitol $(0.1 \%)$, meso-erythritol $(0.1 \%)$, ferulic acid $(0.1 \%)$, D-fucose $(0.1 \%)$, D-galactose $(0.1 \%)$, glucose $(0.1 \%)$, D-glutamic acid $(0.1 \%)$, L-glutamic acid $(0.1 \%)$, DL-glutamine $(0.1 \%)$, L-glutamine $(0.1 \%)$, glycyl-DL-valine $(0.1 \%)$, L-histidine $(0.1 \%), m$-hydroxybenzonic acid $(0.1 \%)$, inositol $(0.1 \%)$, lactose $(0.1 \%)$, D-lyxose $(0.1 \%)$, malic acid $(0.1 \%)$, maltose $(0.1 \%)$, $\mathrm{D}-(+)$ melezitose $(0.1 \%)$, D-methionine $(0.1 \%)$, DL-ornithine monohydrobromide $(0.1 \%)$, DL-proline $(0.1 \%)$, raffinose $(0.1 \%)$, L- $(+)$-rhamnose $(0.1 \%)$, D-ribose $(0.1 \%)$, salicin $(0.1 \%)$, saliginin $(0.1 \%)$, L-serine $(0.1 \%)$, sodium benzoate $(0.1 \%)$, sodium D-gluconate $(0.1 \%)$, sodium hippurate $(0.1 \%)$, sodium oxalate $(0.1 \%)$, sodium salicylate $(0.1 \%)$, sorbose $(0.1 \%)$, sucrose $(0.1 \%)$, syriagic acid $(0.1 \%)$, D- $(-)$-tagatose $(0.1 \%)$, tannic acid $(0.1 \%)$, L-threonine $(0.1 \%)$, D-tryptophan $(0.1 \%)$, L-tryptophan $(0.1 \%)$, D-tyrosine $(0.1 \%)$, uric acid $(0.1 \%)$, D-valine $(0.1 \%)$, valeric acid $(0.1 \%)$, and D-xylose $(0.1 \%)$; (ii) utilization as sole nitrogen sources of $\mathrm{D}$-arginine $(0.1 \%)$, DL-arginine hydrochloride $(0.1 \%)$, DL-aspartic acid $(0.1 \%)$, D-cysteine $(0.1 \%)$, DL-cysteine hydrochloride $(0.1 \%)$, iso-cytosine $(0.1 \%)$, 6-furfuryl aminopurine $(0.1 \%)$, D-glutamic acid $(0.1 \%)$, L-glutamic acid $(0.1 \%)$, DL-glutamine $(0.1 \%)$, glycine $(0.1 \%)$, glycyl-DL-valine $(0.1 \%)$, L-histidine $(0.1 \%)$, D-histidine monohydrochloride $(0.1 \%)$, D-methionine $(0.1 \%)$, L-ornithine monohydrobromide $(0.1 \%)$, DL-proline $(0.1 \%)$, D-serine $(0.1 \%)$, DL-serine $(0.1 \%)$, D-tryptophan $(0.1 \%)$, L-tryptophan $(0.1 \%)$, L-valine $(0.1 \%)$, and DL-valine $(0.1 \%)$; (iii) resistance to the antibiotics chloramphenicol $\left(5,10,25,50\right.$, and $\left.200 \mu \mathrm{g} \cdot \mathrm{ml}^{-1}\right)$, chlortetracycline $\left(5,25\right.$, and $\left.50 \mu \mathrm{g} \cdot \mathrm{ml}^{-1}\right)$, erythromycin $(25$ and 125 $\left.\mu \mathrm{g} \cdot \mathrm{ml}^{-1}\right)$, gentamicin $\left(5,25,50\right.$, and $\left.100 \mathrm{U} \cdot \mathrm{ml}^{-1}\right)$, kanamycin sulfate $\left(5,20,50,100\right.$, and $\left.500 \mathrm{U} \cdot \mathrm{ml}^{-1}\right)$, lincomycin $(500$ $\left.\mu \mathrm{g} \cdot \mathrm{ml}^{-1}\right)$, neomycin $\left(25\right.$ and $\left.75 \mu \mathrm{g} \cdot \mathrm{ml}^{-1}\right)$, penicillin $\mathrm{GK}(5$, $20,40,100$, and $\left.500 \mathrm{U} \cdot \mathrm{ml}^{-1}\right)$, qianglimycin $(1,10,25$, and $\left.100 \mu \mathrm{g} \cdot \mathrm{ml}^{-1}\right)$, streptomycin $\left(1,5,20\right.$, and $\left.120 \mu \mathrm{g} \cdot \mathrm{ml}^{-1}\right)$, 
TABLE 1. Origins and host plants of the bacterial strains examined

\begin{tabular}{|c|c|c|c|c|}
\hline Strain & $\begin{array}{c}\text { CCBAU } \\
\text { no. }{ }^{a}\end{array}$ & Host plant & Origin $^{b}$ & Source ${ }^{a}$ \\
\hline \multicolumn{5}{|l|}{ R. meliloti } \\
\hline USDA $1002^{\mathrm{T}}$ & & & United States & USDA \\
\hline $102 \mathrm{~F} 28$ & & Medicago sativa & & UCD \\
\hline H1 & & Melilotus albus & Heilongjiang & CCBAU \\
\hline \multicolumn{5}{|l|}{ R. leguminosarum } \\
\hline USDA $2370^{\mathrm{T}}$ (R. leguminosarum biovar viceae) & & & United States & USDA \\
\hline $127 \mathrm{~K} 17$ ( $R$. leguminosarum biovar phaseoli) & & & United States & USDA \\
\hline $162 \times 68(R$. leguminosarum biovar trifolii) & & & United States & USDA \\
\hline R. loti ATCC $33669^{\mathrm{T}}$ & & & Canada & Canada \\
\hline \multicolumn{5}{|l|}{ R. huakuii } \\
\hline A106 & & Astragalus sinicus & Hubei & HAU \\
\hline PL-52 & & Astragalus sinicus & Hubei & HAU \\
\hline $103^{\mathrm{T}}$ & & Astragalus sinicus & Nanjing & NAU \\
\hline \multicolumn{5}{|l|}{ R. galegae } \\
\hline HAMBI $540^{\mathrm{T}}$ & & & Finland & HAMBI \\
\hline HAMBI 503 & & & United States & HAMBI \\
\hline HAMBI 1185 & & & United Kingdom & HAMBI \\
\hline \multicolumn{5}{|l|}{ R. fredii } \\
\hline USDA $205^{T}$ & & Glycine soja & Henan & USDA \\
\hline 2408 & & Glycine soja & Liaoning & SFRI \\
\hline USDA 194 & & Glycine soja & Henan & USDA \\
\hline \multicolumn{5}{|l|}{ Rhizobium sp. } \\
\hline CCBAU 105 & & Glycine $\max$ & Xinjiang & CCBAU \\
\hline CCBAU 108 & & Glycine max & Xinjiang & CCBAU \\
\hline CCBAU 109 & & Glycine $\max$ & Xinjiang & CCBAU \\
\hline CCBAU 110 & & Glycine max & Xinjiang & CCBAU \\
\hline R. tropici CIAT $899^{\mathrm{T}}$ & & Phaseolus vulgaris & & CIAT \\
\hline \multicolumn{5}{|l|}{ B. japonicum } \\
\hline USDA $6^{\mathrm{T}}$ & & Glycine max & United States & USDA \\
\hline USDA 110 & & Glycine $\max$ & & USDA \\
\hline B15 & & Glycine max & Liaoning & IOC \\
\hline \multicolumn{5}{|l|}{ Agrobacterium tumefaciens } \\
\hline B6S3 & & & & CCBAU \\
\hline C58 & & & & CCBAU \\
\hline Agrobacterium radiobacter 1.150 & & & & CCBAU \\
\hline \multicolumn{5}{|l|}{ Strains isolated in this study } \\
\hline A-2-Bs & & Lotus sp. & Xinjiang & CCBAU \\
\hline B-6-1 & & Lotus sp. & Xinjiang & CCBAU \\
\hline $\mathrm{I} 12$ & 57002 & Centrosema pubescens & Hainan & CCBAU \\
\hline I17 & 57517 & Centrosema pubescens & Hainan & CCBAU \\
\hline 128 & 57520 & Centrosema pubescens & Hainan & CCBAU \\
\hline H17 & 57502 & Centrosema pubescens & Hainan & CCBAU \\
\hline H68 & 57507 & Centrosema pubescens & Hainan & CCBAU \\
\hline H112 & 57509 & Centrosema pubescens & Hainan & CCBAU \\
\hline 17 & 57514 & Crotalaria anagyroides & Hainan & CCBAU \\
\hline I14 & 57515 & Crotalaria anagyroides & Hainan & CCBAU \\
\hline $\mathrm{I} 25$ & 57519 & Crotalaria juncea & Hainan & CCBAU \\
\hline I61 & 57522 & Crotalaria chinensis & Hainan & CCBAU \\
\hline 170 & 57523 & Crotalaria hainanensis & Hainan & CCBAU \\
\hline I79 & 57524 & Crotalaria linifolia & Hainan & CCBAU \\
\hline S49 & 57532 & Crotalaria mucronata & Hainan & CCBAU \\
\hline $\mathrm{I} 80$ & 57525 & Dalbergia obtusifolia & Hainan & CCBAU \\
\hline $\mathrm{H} 54$ & 57505 & Dalbergia odorifera & Hainan & CCBAU \\
\hline H101 & 57508 & Dalbergia balansae & Hainan & CCBAU \\
\hline $\mathrm{I} 15$ & 57516 & Desmodium heterocarpon & Hainan & CCBAU \\
\hline 120 & 57003 & Desmodium gyroides & Hainan & CCBAU \\
\hline $\mathbf{I} 32$ & 57008 & Desmodium triquetrum & Hainan & CCBAU \\
\hline I 88 & 57527 & Desmodium biarticulatum & Hainan & CCBAU \\
\hline I94 & 57531 & Desmodium heterocarpon & Hainan & CCBAU \\
\hline $\mathrm{H} 22$ & 57503 & Desmodium triangulare & Hainan & CCBAU \\
\hline H121 & 57535 & Desmodium intortum & Hainan & CCBAU \\
\hline I 23 & 57518 & Desmodium intortum & Hainan & CCBAU \\
\hline $\mathrm{I} 30$ & 57007 & Desmodium biandum & Hainan & CCBAU \\
\hline 166 & 57015 & Desmodium sinuatum & Hainan & CCBAU \\
\hline $\mathrm{H} 50$ & 57504 & Desmodium triangulare & Hainan & CCBAU \\
\hline H62 & 57506 & Desmodium sp. & Hainan & CCBAU \\
\hline $\mathrm{H} 123$ & 57511 & Desmodium triquetrum & Hainan & CCBAU \\
\hline $\mathrm{H} 33$ & 57021 & Desmodium triquetrum & Hainan & CCBAU \\
\hline
\end{tabular}


TABLE 1-Continued

\begin{tabular}{|c|c|c|c|c|c|}
\hline & Strain & $\begin{array}{c}\text { CCBAU } \\
\text { no. }^{a}\end{array}$ & Host plant & Origin $^{b}$ & Source $^{a}$ \\
\hline H14 & & 57019 & Desmodium heterophyllum & Hainan & CCBAU \\
\hline 186 & & 57526 & Indigofera litoralis & Hainan & CCBAU \\
\hline I40 & & 57521 & Indigofera suffruticosa & Hainan & CCBAU \\
\hline I3 & & 57512 & Macroptilium atropurpureum & Hainan & CCBAU \\
\hline 127 & & 57006 & Macroptilium lathyroides & Hainan & CCBAU \\
\hline $\mathrm{H} 24$ & & 57536 & Pachyrhizus erosus & Hainan & CCBAU \\
\hline H31 & & 57020 & Pueraria phaseoloides & Hainan & CCBAU \\
\hline H122 & & 57510 & Pueraria phaseoloides & Hainan & CCBAU \\
\hline S74 & & 57533 & Pueraria phaseoloides & Hainan & CCBAU \\
\hline S88 & & 57534 & Pueraria phaseoloides & Hainan & CCBAU \\
\hline 15 & & 57513 & Vigna sinensis & Hainan & CCBAU \\
\hline $\mathrm{I} 2$ & & 57001 & Stylosanthes guyanensis & Hainan & CCBAU \\
\hline S68 & & 57026 & Stylosanthes hamata & Hainan & CCBAU \\
\hline S71 & & 57027 & Stylosanthes guyanensis & Hainan & CCBAU \\
\hline I64 & & 57013 & Tephrosia candida & Hainan & CCBAU \\
\hline S25 & & 57022 & Tephrosia candida & Hainan & CCBAU \\
\hline S93 & & 57028 & Tephrosia purpurea & Hainan & CCBAU \\
\hline S38 & & 57023 & Leucaena diversifolia & Hainan & CCBAU \\
\hline $\mathbf{S} 43$ & & 57024 & Leucaena leucocephala & Hainan & CCBAU \\
\hline H3 & & 57016 & Leucaena sp. & Hainan & CCBAU \\
\hline H7 & & 57017 & Leucaena sp. & Hainan & CCBAU \\
\hline $\mathrm{H} 8$ & & 57018 & Leucaena leucocephala & Hainan & CCBAU \\
\hline I54 & & 57012 & Acacia sinuata & Hainan & CCBAU \\
\hline S62 & & 57025 & Cassia mimosoides & Hainan & CCBAU \\
\hline I65 & & 57014 & Arachis hypogaea & Hainan & CCBAU \\
\hline $\mathrm{I} 22$ & & 57004 & Sesbania cannabina & Hainan & CCBAU \\
\hline $\mathrm{I} 24$ & & 57005 & Calopogonium mucunoides & Hainan & CCBAU \\
\hline 133 & & 57009 & Zornia diphylla & Hainan & CCBAU \\
\hline $\mathrm{I} 36$ & & 57010 & Uraria crinita & Hainan & CCBAU \\
\hline I39 & & 57011 & Uraria lagopodioides & Hainan & CCBAU \\
\hline 191 & & 57528 & Alysicarpus vaginalis & Hainan & CCBAU \\
\hline 192 & & 57529 & Alysicarpus vaginalis & Hainan & CCBAU \\
\hline 193 & & 57530 & Alysicarpus vaginalis & Hainan & CCBAU \\
\hline
\end{tabular}

${ }^{a}$ CCBAU, Culture Collection of Beijing Agricultural University, Beijing, People's Republic of China; HAU, Huazhong Agricultural University, Wuhan, People's Republic of China; HAMBI, Department of Microbiology, University of Helsinki, Helsinki, Finland; IOC, Institute of Oil Crops, Chinese Academy of Agricultural Science, Wuhan, People's Republic of China; NAU, Nanjing Agricultural University, Nanjing, People's Republic of China; SFRI, Soil and Fertilizer Research Institute, Chinese Academy of Agricultural Science, Beijing, People's Republic of China; UCD, University of California, Davis; USDA, United States Department of Agriculture, Beltsville, Md.

${ }^{b}$ All locations in the People's Republic of China unless indicated otherwise.

terramycin $\left(5,10,30\right.$, and $\left.100 \mu \mathrm{g} \cdot \mathrm{ml}^{-1}\right)$, tetracycline hydrochloride $\left(5,20 ; 40\right.$, and $\left.100 \mu \mathrm{g} \cdot \mathrm{ml}^{-1}\right)$, and maidimycin $(20$, 40 , and $100 \mu \mathrm{g} \cdot \mathrm{ml}^{-1}$ ); (iv) resistance to the dyes acridine orange $(0.1$ and $0.05 \%)$, bromocresol purple $(0.1 \%)$, bromophenol blue $(0.1 \%)$, bromothymol blue $(0.1$ and $0.05 \%)$, Giemsa stain $(0.1 \%)$, methyl green $(0.1 \%)$, methyl red $(0.1 \%)$, methylene blue $(0.1 \%)$, methyl violet $(0.1 \%)$, nile blue $(0.1 \%)$, phenol red $(0.1 \%)$, chrysoidine $(0.1 \%)$, gentian violet $(0.05 \%)$, rose bengal $(0.08 \%)$, neutral red $(0.20 \%)$, and congo red $(0.20 \%)$; (v) tolerance to the chemicals bismuth sulfate $(0.5$, 1.0 , and $2.0 \%$ ), potassium tellurite $(0.01,0.02$, and $0.05 \%)$, sodium desoxycholate $(0.025,0.05,0.1,0.2$, and $0.5 \%)$, and sodium nitrite $(0.025,0.05$, and $0.1 \%)$; (vi) growth on yeast extract-mannitol agar supplemented with $\mathrm{NaCl}$ at concentrations of $0.5,1.0,1.5,2.0,3.0$, and $4.0 \%$; (vii) growth at $\mathrm{pH} 4.5$, 5.5, 9.0, and 10.0; (viii) growth at $4,37,41$, and $46^{\circ} \mathrm{C}$; (ix) reactions in litmus milk; (x) reduction of methylene blue, nitrite, and nile blue; (xi) acid or alkali production on yeast extract-mannitol agar; and (xii) production of urease, catalase, and cytochrome oxidase.

Most of the biological tests were conducted by using plates inoculated with a multipoint inoculator (12); about $10^{5}$ cells per point was used as the inoculum. Other tests were conducted in broth. Unless indicated otherwise, the cultures were incubated at $28^{\circ} \mathrm{C}$. Growth of the fast-growing and slowly growing strains was observed after incubation for 3 to 5 and 7 to 10 days, respectively. Carbohydrate utilization and organic acid utilization were determined on the medium of White (26), which contained the trace elements of medium Cs7 (17). Utilization of sole nitrogen sources was examined by using the same medium, except that $\mathrm{NaNO}_{3}$ was replaced with various nitrogen sources at a concentration of $0.1 \%$ (wt/vol). Resistance to antibiotics and dyes, tolerance of $\mathrm{NaCl}$ at various concentrations and the $\mathrm{pH}$ range for growth were examined by using yeast extract-mannitol agar (11) and the method of Thompson and Skerman (22). Nitrate reduction was tested by using a modification of the method of Pohiman (18), as described previously (2).

Computer analysis. The coding of characteristics, calculating similarity with the simple matching coefficient, determining the central strain of each phenotypic group, and clustering by the unweighted average linkage method were all performed by the methods of Sneath and Sokal (21). The analysis was performed at the Computer Research Labora- 


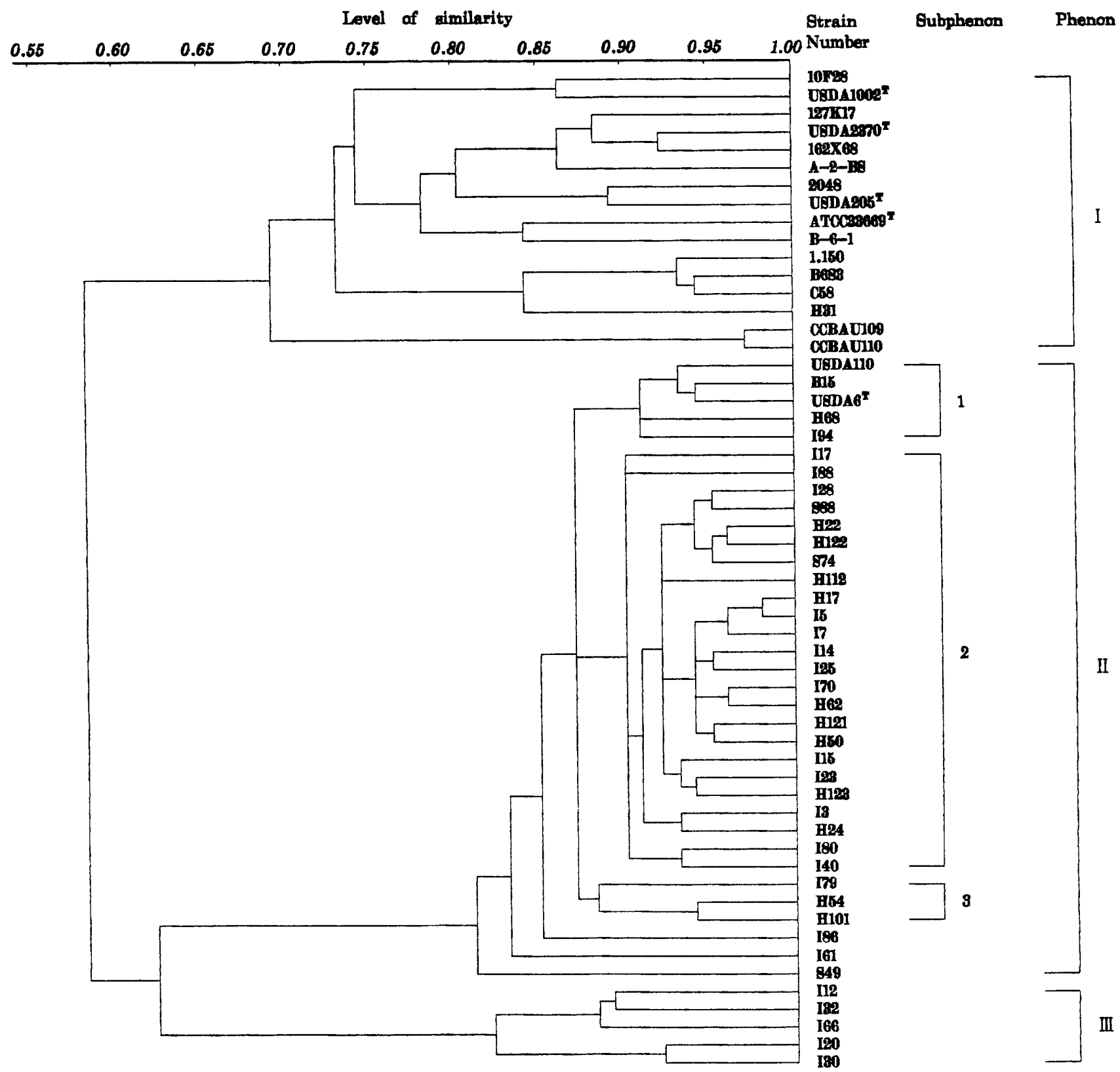

FIG. 1. Phenetic dendrogram showing the relationships among slowly growing rhizobia isolated from Hainan Province and reference strains.

tory, Institute of Microbiology, Academica Sinica, Beijing, People's Republic of China.

Estimation of DNA base compositions and levels of DNADNA hybridization. DNAs were isolated and purified by Marmur's method, with some modifications (14). The average $\mathrm{G}+\mathrm{C}$ content of the DNA of each strain was measured by the thermal denaturation method (15), and the equation of De Ley (3) was used. Escherichia coli $\mathrm{K}-12$ was used as the standard. The levels of DNA homology were determined by the initial renaturation rate method (4).

\section{RESULTS AND DISCUSSION}

Numerical analysis of slowly growing rhizobia obtained from Hainan Province. The numerical taxonomic analysis was conducted in two steps. First, 32 slowly growing strains and 6 fast-growing strains isolated from Hainan Province were compared with 18 reference strains, including the type strains of previously described species belonging to the genera Rhizobium, Bradyrhizobium, and Agrobacterium, by performing a numerical analysis of 193 phenotypic features. The resulting dendrogram is shown in Fig. 1.

Figure 1 shows that all of the strains examined clustered into three phena at a level of similarity of $62 \%$.

Phenon I, whose members clustered at a level of similarity of $69 \%$, contained 13 representatives of Rhizobium and Agrobacterium species. Two strains isolated from Lotus sp. (strains A-2-BS and B-6-1 from Xinjiang Region) and one strain isolated from Pueraria phaseoloides (strain $\mathrm{H} 31$ from Hainan Province) also fell into this group. 
TABLE 2. Distinctive features of the genus Rhizobium and the slowly growing and fast-growing rhizobia isolated from Hainan Province

\begin{tabular}{cccc}
\hline Characteristic & $\begin{array}{c}\text { Rhizo- } \\
\text { bium }\end{array}$ & $\begin{array}{c}\text { Slowly } \\
\text { growing } \\
\text { rhizobia }\end{array}$ & $\begin{array}{c}\text { Fast- } \\
\text { growing } \\
\text { rhizobia }\end{array}$ \\
\hline
\end{tabular}
Utilization of the following compounds
as sole carbon sources:

Amygdalin

Dulcitol

Lactose

Sodium oxalate

Sucrose

Salicin

Uric acid

Dextrin

D-Arginine

DL-Arginine

D-Glutamic acid

L-Histidine

DL-Ornithine monohydrobromide

D-Tryptophan

L-Threonine

DL-Asparagine

D-Tyrosine

Utilization of the following compounds as sole nitrogen sources: DL-Cysteine hydrochloride Histidine monohydrochloride D-Tryptophan

Resistance to antibiotics

Chlortetracycline $\left(25 \mu \mathrm{g} \cdot \mathrm{ml}^{-1}\right)$

Neomycin $\left(25 \mu \mathrm{g} \cdot \mathrm{ml}^{-1}\right)$

Qianglimycin $\left(1 \mu \mathrm{g} \cdot \mathrm{ml}^{-1}\right)$

Qianglimycin $\left(10 \mu \mathrm{g} \cdot \mathrm{ml}^{-1}\right)$

Qianglimycin $\left(25 \mu \mathrm{g} \cdot \mathrm{ml}^{-1}\right)$
Streptomycin $\left(20 \mu \mathrm{g} \cdot \mathrm{ml}^{-1}\right)$

Terramycin $\left(10 \mu \mathrm{g} \cdot \mathrm{ml}^{-1}\right)$

Terramycin $\left(30 \mu \mathrm{g} \cdot \mathrm{ml}^{-1}\right)$

Tetracycline $\mathrm{HCl}\left(5 \mu \mathrm{g} \cdot \mathrm{ml}^{-1}\right)$

Tetracycline $\mathrm{HCl}\left(20 \mu \mathrm{g} \cdot \mathrm{ml}^{-1}\right)$

Tetracycline $\mathrm{HCl}\left(40 \mu \mathrm{g} \cdot \mathrm{ml}^{-1}\right)$

Resistance to dyes

Bromothymol blue $(0.1 \%)$

Bromothymol blue $(0.05 \%)$

Chrysoidine $(0.1 \%)$

Growth at:

pH 4.5

pH 9.0

Methylene blue reduction

Litmus milk alkali production

Litmus milk peptonization

Acid production

Alkali production

$a+$, at least $95 \%$ of the strains are positive; $d$, less than $95 \%$ but more than $5 \%$ of the strains are positive; - , less than $5 \%$ of the strains are positive.

The members of phenon II, which contained 32 strains of slowly growing rhizobia obtained from Hainan Province and three representative strains of Bradyrhizobium japonicum, clustered at a level of similarity of $81 \%$. In addition, at a level of similarity of $88 \%$, phenon II was divided into three subphena. Subphenon 1, whose members clustered at a level of similarity of $91 \%$, was composed of three representative strains of $B$. japonicum and two strains isolated from Centrosema pubescens and Desmodium heterocarpon. Subphenon 2 formed at a level of similarity of $90 \%$ and contained 24 strains isolated from members of nine host plant genera,

including the genera Centrosema (strains I17, I28, H112, and H17 from Centrosema pubescens), Desmodium (strain I88 from Desmodium biarticulatum, strains H22 and H50 from Desmodium triangulare, strain H62 from Desmodium sp., strains H121 and I23 from Desmodium intortum, strain I15 from Desmodium heterocarpon, strain $\mathrm{H} 123$ from Desmodium triquetrum), Pueraria (strains $\mathrm{H} 122$ and S74 from Pueraria phaseoloides), Vigna (strain I5 from Vigna sinensis), Crotalaria (strains I7 and I14 from Crotalaria anagyroides, strain 125 from Crotalaria juncea, strain 170 from Crotalaria hainanensis), Macroptilium (strain I3 from Macroptilium atropurpureum cv. siratro), Paehyrhizus (strain H24 from Pachyrhizus erosus), Dalbergia (strain I80 from Dalbergia obtusifolia), and Indigofera (strain I40 from Indigofera suffruticosa). Strain H22 was the central strain of phenon II. Subphenon 3 was composed of three strains isolated from the genera Crotalaria (strain 179 from Crotalaria linifolia) and Dalbergia (strain H54 from Dalbergia odorifera, strain H101 from Dalbergia balansae). These strains were linked at a similarity level of $88 \%$. Three strains (strain I86 from Indigofera litoralis, strain I61 from Crotalaria chinensis, strain S49 from Crotalaria mucronata) did not form a subcluster; these strains joined the three subphena at levels of similarity of 85,83 , and $81 \%$, respectively.

The slowly growing rhizobia isolated from Hainan Province (phenon II, including three subphena), clustered with the representative strains of $B$. japonicum at a high similarity level $(81 \%)$ and were distinctly separated from the other two phena. On the basis of the view of Sneath (20) that the level of similarity of strains belonging to the same species is about $80 \%$, it seemed that the slowly growing rhizobia isolated from Hainan Province are $B$. japonicum strains and that the three subphena are three subspecies of $B$. japonicum.

Five strains were isolated from Centrosema pubescens; one of these strains (H68) fell into subphenon 1 , and the other four strains (I17, I28, H112, H17) fell into subphenon 2. Nine strains were isolated from Desmodium spp.; one of these strains (194) fell into subphenon 1, and the other 8 strains (I88, H22, H62, H121, H50, I15, I23, H123) fell into subphenon 2. Seven strains were isolated from Crotalaria spp.; four of these strains (I7, I14, I25, I70) fell into subphenon 2, one strain (I79) fell into subphenon 3, and two strains (I61, S49) did not fall into any subphenon. These results show that slowly growing rhizobia may be members of different clusters even though they were isolated from members of the same host plant genus. Thus, the clustering of the slowly growing rhizobia was not closely related to the genera of their host plants. This indicated that the host specificity of the slowly growing rhizobia is very weak. Meanwhile, the high level of similarity in phenon II indicated that all of the slowly growing rhizobia are closely related to each other.

Phenon III contained five fast-growing rhizobia isolated from Hainan Province, and its members clustered at a level of similarity of $82 \%$. These organisms were isolated from members of the genera Centrosema (strain I12 from Centrosema pubescens) and Desmodium (strain I32 from Desmodium triquetrum, strain I66 from Desmodium sinuatum, strain 120 from Desmodium gyroides, strain I30 from Desmodium biandum). These fast-growing rhizobia are distinctly different from either the slowly growing rhizobia or the previously described fast-growing species shown in Fig. 1. Figure 1 also shows that nine slowly growing rhizobia isolated from Desmodium spp. (strain I94 from Desmodium heterocarpon var. stigosum, strain I88 from Desmodium biarticulatum, strains $\mathrm{H} 22$ and $\mathrm{H} 50$ from Desmodium triangulare, strain H62 from Desmodium sp., strains H121 and 


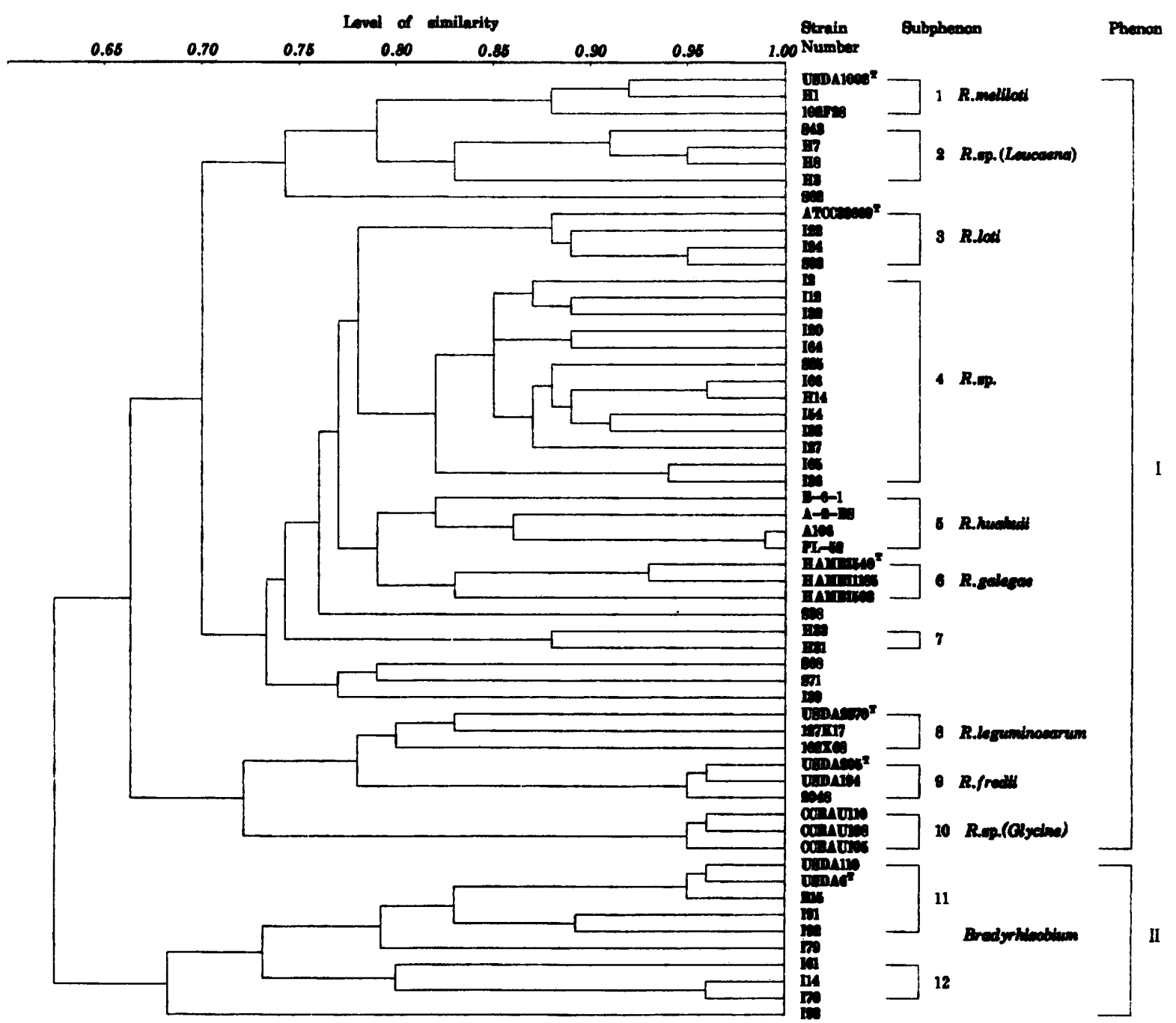

FIG. 2. Phenetic dendrogram showing the relationships among fast-growing rhizobia isolated from Hainan Province and reference strains.

I23 from Desmodium intortum; strain I15 from Desmodium heterocarpon, strain $\mathrm{H123}$, from Desmodium triquetrum) fell into phenon II, while four fast-growing rhizobia isolated from members of the same genus of host plants (strain I32 from Desmodium triquetrum, strain I66, from Desmodium sinuatum, strain 120 from Desmodium gyroides, strain I30 from Desmodium biandum) fell into phenon III. These results indicate that slowly growing and fast-growing rhizobia may fall into different phena that are distantly related to each other even though they were isolated from members of the same genus of host plants.

The differential characteristics of the three phena are shown in Table 2. The data show that the fast-growing Hainan Province rhizobia could utilize a wider range of carbon and nitrogen sources than previously recognized Rhizobium and Bradyrhizobium strains could. These organisms were also more resistant than Rhizobium strains and more susceptible than Bradyrhizobium strains to the antibiotics used in this study, and they could grow at either $\mathrm{pH} 4.5$ or $\mathrm{pH} 9.0$.

Numerical analysis of fast-growing rhizobia from Hainan Province. Since the fast-growing Hainan Province rhizobia are very different from previously described Rhizobium strains, we increased the number of fast growers to 27 isolates obtained from a wide range of leguminous plants growing in Hainan Province and conducted a second numerical analysis with 23 representative strains belonging to previously recognized $R$ hizobium species, including $R$ hizobium huakuii and Rhizobium galegae $(2,13)$. A total of 143 phenotypic characteristics were used. The results are shown in the dendrogram in Fig. 2.

Figure 2 shows that all of the strains examined clustered into two phena at a similarity level of $66 \%$. Phenon I included 27 strains of fast-growing rhizobia obtained from Hainan Province and 18 representative strains of $R$ hizobium species. A total of 10 subphena were formed at a level of similarity of $80 \%$. Subphena $1,5,6,8,9$, and 10 contained the known Rhizobium meliloti, $R$. huakuii, $R$. galegae, Rhizobium leguminosarum, Rhizobium fredii, and Rhizobium sp. strains, respectively. Subphenon 2 contained four strains isolated from Leucaena spp. Subphenon 3 contained the type culture of Rhizobium loti and three strains obtained from Sesbania cannabina, Calopoginium mucunoides, and Tephrosia purpurea. Subphenon 4 contained 13 strains iso- 
TABLE 3. Levels of DNA relatedness between fast-growing rhizobia isolated from Hainan Province and belonging to subphenon $2^{a}$

\begin{tabular}{lrrrr}
\hline \multirow{4}{*}{ Strain } & \multicolumn{4}{c}{ \% Homology with strain: } \\
\cline { 2 - 5 } & S43 & H7 & H8 & H3 \\
\hline S43 & 100 & & & \\
H7 & 86 & 100 & 100 & \\
H8 & 73 & 78 & 73 & 100 \\
H3 & 71 & 84 &
\end{tabular}

${ }^{a}$ See Fig. 2.

lated from 12 species belonging to nine genera of host plants (Stylosanthes guyanensis, Centrosema pubescens, Desmodium triquetrum, Desmodium gyroides, Desmodium sinuatum, Desmodium heterophyllum, Tephrosia candida, Acacia sinuata, Zornia diphylla, Macroptilium lathyroides, Arachis hypogaea, and Uraria crinita). Subphenon 7 contained two strains isolated from Desmodium triquetrum and Pueraria phaseoloides.

Phenon II contained three strains of $B$. japonicum and seven slowly growing rhizobia obtained from Hainan Province. Two subphena were formed at a level of similarity of $80 \%$. Subphenon 11 contained three representative strains of B. japonicum and two strains isolated from Alysicarous vaginalis; three strains isolated from Crotalaria chinensis, Crotalaria anagyroides, and Crotalaria hainanensis made up subphenon 12 .

Five fast-growing rhizobia (S62, S38, S68, S71, 139) and two slowly growing rhizobia (I79, I93) did not fall into any subphenon at a similarity level of $80 \%$.

DNA relatedness of fast-growing rhizobia isolated from Hainan Province. The levels of DNA homology and the DNA base compositions of representative strains of rhizobia belonging to each subphenon isolated from Hainan Province, as well as type strains of previously recognized Rhizobium and Bradyrhizobium species, were determined by the spectrophotometric method (3). The results showed that the levels of DNA relatedness between strains in subphenon 2 ranged from 71 to $86 \%$ (Table 3 ). The levels of DNA relatedness for four strains in subphenon 3 , including $R$. loti ATCC $33669^{\mathrm{T}}(\mathrm{T}=$ type strain $)$, ranged from 78 to $91 \%$ (Table 4). And the levels of DNA relatedness for five strains in subphenon 4 ranged from 75 to $93 \%$ (Table 5). Strains that exhibited more than $70 \%$ DNA-DNA relatedness were members of a specific group, and the levels of DNA homology between the groups were less than $30 \%$. The levels of DNA homology between most representative strains of the three subphena and eight type strains of previously described Rhizobium and Bradyrhizobium species ranged from 0 to $46 \%$; the only exception was the $82 \%$ level of homology

TABLE 4. Levels of DNA relatedness between fast-growing rhizobia isolated from Hainan Province and belonging to subphenon $3^{a}$

\begin{tabular}{lrrrc}
\hline \multirow{2}{*}{ Strain } & \multicolumn{5}{c}{ \% Homology with strain: } \\
\cline { 2 - 5 } & I22 & S93 & I24 & ATCC 33669 \\
\hline I22 & 100 & & & \\
S93 & 78 & 100 & 100 & 82 \\
I24 & 91 & 82 & 100 \\
\hline
\end{tabular}

${ }^{a}$ See Fig. 2.
TABLE 5. Levels of DNA relatedness between fast-growing rhizobia isolated from Hainan Province and belonging to subphenon $4^{a}$

\begin{tabular}{lrrrrr}
\hline \multirow{2}{*}{ Strain } & \multicolumn{5}{c}{ \% Homology with strain: } \\
\cline { 2 - 6 } & I12 & I20 & I36 & I54 & I66 \\
\hline I12 & 100 & & & & \\
I20 & 82 & 100 & & & \\
I36 & 85 & 92 & 100 & & \\
I54 & 78 & 78 & 93 & 100 & \\
I66 & 77 & 89 & 75 & 80 & 100 \\
\hline
\end{tabular}

${ }^{a}$ See Fig. 2.

observed between strains ATCC $33669^{\mathrm{T}}$ and I24, which were in the same subphenon, subphenon 3 (Table 6). The results described above indicated that strains isolated from Sesbania cannabina, Calopogonium mucunoides, and Tephrosia purpurea should be placed in $R$. loti. Subphenon 2 contained four strains isolated from Leucaena spp. These organisms constituted a distinct group that was different from Rhizobium tropici (16). And subphenon 4 was also an independent group different from previously recognized Rhizobium species.

The DNA $\mathrm{G}+\mathrm{C}$ contents of representative strains of subphena 2 through 4 , as well as the type strains of $R$. leguminosarum biovar viceae and $R$. loti, ranged from 59 to $64 \mathrm{~mol} \%$; these values were within the range expected for the genus Rhizobium (11).

According to the minimal standards for description of new genera and species of root- and stem-nodulating bacteria proposed by the Subcommittee on the Taxonomy of Rhizobium and Agrobacterium (9), subphenon 4 might be a new Rhizobium species on the basis of the results of the numerical taxonomy and DNA relatedness analysis. In order to determine its phylogenetic position, DNA-rRNA hybridization or 16S rRNA sequence analysis will be required.

From the data described above, it seemed that the slowly growing rhizobia isolated from various legumes growing in a tropical region were very closely related but the fast-growing rhizobia were highly diverse and that the classification of these organisms is not closely related to the identities of the host plants.

TABLE 6. Levels of DNA relatedness between representative strains belonging to subphena 2 through 4 and type strains of Rhizobium and Bradyrhizobium species ${ }^{a}$

\begin{tabular}{lrrr}
\hline \multirow{2}{*}{ Strain } & \multicolumn{3}{c}{ \% Homology with strain: } \\
\cline { 2 - 4 } & $\mathbf{I 6 6}$ & H7 & I24 \\
\hline USDA 1002 $^{\mathrm{T}}$ & 0 & 0 & 0 \\
USDA 2370 $^{\mathrm{T}}$ & 46 & 2 & 0 \\
ATCC 33669 & 0 & 0 & 82 \\
CCBAU 110 & 8 & 32 & 0 \\
USDA 205 $^{\mathrm{T}}$ & 0 & 18 & 0 \\
CCBAU 2609 & 0 & 40 & 35 \\
HAMBI 540 & 0 & 0 & 0 \\
CIAT 899 & 11 & 0 & \\
USDA 6 $^{\mathrm{T}}$ & 10 & 0 & 0 \\
I66 & 100 & 29 & 24 \\
H7 & & 100 & 8 \\
I24 & & & 100 \\
\hline${ }^{a}$ See Fig. 2. & & &
\end{tabular}

${ }^{a}$ See Fig. 2. 


\section{ACKNOWLEDGMENTS}

We are indebted to Shijie Yu and Xiaofeng Deng, Huanan College of Tropical Crops, Hainan, People's Republic of China, for help with nodule collection and plant species identification. We thank Yufeng Zhao and Juncai Ma, Institute of Microbiology, Academia Sinica, Beijing, People's Republic of China, for performing the computer analysis. We also thank Xiaodong $\mathrm{Xu}$, Department of Microbiology, Beijing Agricultural University, Beijing, People's Republic of China, for drawing the dendrograms.

Funding for this research was provided by the National Natural Sciences Foundation and the National Education Commission Foundation of the People's Republic of China.

\section{REFERENCES}

1. Allen, O. N., and E. K. Allen. 1981. The Leguminosae: a source book of characteristics, uses and nodulation. The University of Wisconsin Press, Madison.

2. Chen, W. X., G. S. Li, Y. L. Qi, E. T. Wang, H. L. Yuan, and J. L. Li. 1991. Rhizobium huakuii sp. nov. isolated from the root nodules of Astragalus sinicus. Int. J. Syst. Bacteriol. 41:275280.

3. De Ley, J. 1970. Reexamination of the association between melting point, buoyant density, and chemical base composition of deoxyribonucleic acid. J. Bacteriol. 101:738-754.

4. De Ley, J., H. Cattoir, and A. Reynaerts. 1970. The quantitative measurement of DNA hybridization from renaturation rates. Eur. J. Biochem. 12:133-142.

5. Dreyfus, B., J. L. Garcia, and M. Gillis. 1988. Characterization of Azorhizobium caulinodans gen. nov., sp. nov., a stemnodulating nitrogen-fixing bacterium isolated from Sesbania rostrata. Int. J. Syst. Bacteriol. 38:89-98.

6. Dreyfus, B. L., and Y. R. Dommergues. 1981. Nodulation of Acacia species by fast- and slow-growing tropical strains of rhizobium. Appl. Environ. Microbiol. 41:97-99.

7. Eaglesham, A. R. J., M. D. Stowers, M. L. Maina, B. J. Goldman, M. J. Sinclair, and A. Ayanaba. 1987. Physiological and biochemical aspects of diversity of Bradyrhizobium sp. (Vigna) from three West African soils. Soil Biol. Biochem. 19:575-581.

8. Graham, P. H., and S. C. Harris (ed.). 1982. Biological nitrogen fixation technology for tropical agriculture. Centro Internacional de Agricultura Tropical, Cali, Colombia.

9. Graham, P. H., M. J. Sadowsky, H. H. Keyser, Y. M. Barnet, R. S. Bradley, J. E. Cooper, D. J. De Ley, B. D. W. Jarvis, E. B. Roslycky, B. W. Strijdon, and J. P. W. Young. 1991. Proposed minimal standards for the description of new genera and species of root- and stem-nodulating bacteria. Int. J. Syst. Bacteriol. 41:582-587.

10. Herrera, M. A., E. J. Bedmar, and J. Olivares. 1985. Host specificity of Rhizobium strains isolated from nitrogen-fixing trees and nitrogenase activities of strain GRH2 in symbiosis with Prosopis chilensis. Plant Sci. 42:177-182.

11. Jordon, D. C. 1984. Family III. Rhizobiaceae, Conn 1938, p. 234-256. In N. R. Krieg and J. G. Holt (ed.), Bergey's manual of systematic bacteriology, vol. 1. The Williams \& Wilkins Co., Baltimore.
12. Josey, D. P., J. L. Beyhan, A. W. B. Johnson, and J. E. Beringer. 1979. Strain identification in Rhizobium using intrinsic antibiotic resistance. J. Appl. Bacteriol. 46:343-350.

13. Lindstrom, K. 1989. Rhizobium galegae, a new species of legume root nodule bacteria. Int. J. Syst. Bacteriol. 39:365-367.

14. Marmur, J. 1961. A procedure for the isolation of deoxyribonucleic acid from microorganisms. J. Mol. Biol. 3:208-218.

15. Marmur, J., and P. Doty. 1962. Determination of the base composition of DNA from its thermal denaturation temperature. J. Mol. Biol. 5:109-118.

16. Martinez-Romero, E., L. Segovia, F. M. Mercante, A. A. Franco, P. Graham, and M. A. Pardo. 1991. Rhizobium tropici, a novel species nodulating Phaseolus vulgaris L. beans and Leucaena sp. trees. Int. J. Syst. Bacteriol. 41:417-426.

17. Pagan, J. D., J. J. Child, W. R. Scowcroft, and A. H. Gibson. 1975. Nitrogen fixation by Rhizobium cultured on a defined medium. Nature (London) 256:406-407.

18. Pohlman, G. C. 1931. Changes produced in nitrogenous compounds by Rhizobium meliloti and $R$. japonicum. Soil Sci. 31:385.

19. Rinaudo, G., S. Orenga, M. P. Fernandez, H. Meugnier, and R. Bardin. 1991. DNA homology among members of the genus Azorhizobium and other stem- and root-nodulating bacteria isolated from the tropical legume Sesbania rostrata. Int. J. Syst. Bacteriol. 41:114-120.

20. Sneath, P. H. A. 1984. Numerical taxonomy, p. 5-7. In N. R. Krieg and J. G. Holt (ed.), Bergey's manual of systematic bacteriology, vol. 1. The Williams \& Wilkins Co., Baltimore.

21. Sneath, P. H. A., and R. B. Sokal. 1973. Numerical taxonomy. The principles and practice of numerical classification. W. H. Freeman and Co., San Francisco.

22. Thompson, J. P., and V. B. D. Skerman. 1979. Azotobacteriaceae. Academic Press, Inc., New York.

23. Trinick, M. J. 1968. Nodulation of tropical legumes. I. Specificity in the Rhizobium symbiosis of Leucaena leucocephala. Exp. Agric. 4:243-253.

24. Trinick, M. J. 1980. Relationships amongst the fast-growing rhizobia of Lablab purpureus, Leucaena leucocephala, Mimosa spp., Acacia farnesiana and Sesbania grandiflora and their affinities with other rhizobial groups. J. Appl. Bacteriol. 49:3953.

25. Wang, C. H., R. Patchamuthu, H. Meyer, Z. A. C. E. Pankhurst, and W. J. Broughton. 1988. Rhizobia in tropical legumes: ineffective nodulation of Arachis hypogaea L. by fast-growing strains. Soil Biol. Biochem. 20:677-681.

26. White, L. O. 1972. The taxonomy of the crown gall organism Agrobacterium tumefaciens and its relationship to rhizobia and other agrobacteria. J. Gen. Microbiol. 72:565-574.

27. Zhang, X. P., R. Harper, M. Karsisto, and K. Lindstrom. 1991. Diversity of rhizobium bacteria isolated from the root nodules of leguminous trees. Int. J. Syst. Bacteriol. 41:104-113.

28. Zhang, X. P., M. Karsisto, and K. Lindstrom. 1992. Assessment of the competitiveness of fast-growing rhizobia infecting Acacia senegal using antibiotic resistance and melanin production as identification markers. World J. Microbiol. Biotechnol. 8:199 205. 